diaspora writers. It is proved that ornamentalism proves to be sophistication of expressions, richness of metaphors and comparisons, associativeness of thoughts, images, other artistic means of representation. Characteristic rejection of the plot action is a sign of ornamental memoir prose, the aborted phrase, the sentence is compensated by the gradual reflections of the author. Quite often the authors resort to the contrast, the contradiction of ontological, skillfully modeled life situations. The poetics of the contrast of the environment, the world and a man in it is achieved through artistic poetic images, events, documentary facts. It is revealed that ornamentalism is a stylistic characteristic, a feature of lyrical memoir prose, in which the expression of memories acts as a vivid color, which is the basis and stylistic decoration of the creative work of diaspora writers. Lyrical style is expressed in colors, sounds, smells, image of tactile verbal model.

Key words: ornamental prose, story lyrics, style, ego-text, narrative structures, meta-genre.

Дата надходження статті: «19» березня 2019 р.

Дата прийняття до друку: «03» квітня 2019 р.

УДК 821.161.2.09»18/21»:1

DOI: 10.31475/fil.dys.2019.09.05

ДМИТРО ДРОЗДОВСькИй, кандидат фбілологічних наук (s. Kü̈в)

\title{
Містерія й карнавал як метаформи постпостмодерністського британського роману
}

У статті йдеться про реалістичні тенденцї, експліковані в сучасному британському романі. Розвинуто конщепцію Б. Шалагінова про містерію й карнавал як два метажанри світової літератури. Доведено, що в англійськолу ролані “Хларний атлас" Д. Мітчелла репрезентовано карнавальні та містеріальні елеленти, причолу центральне місие посідає сале містерія, яка переживає занепад у літературах $X X \quad \mathrm{~cm}$. З’ясовано, що в британській постпостлодерністській літературі відбувається співіснування двох зазначених метабборл. Окреслено світоглядну специфіку (пост)реалізлу, експлікованого в сучаснолу ролані Великої Британії. Наголошено на аспектах медикалізованого пізнання дійсності персонажали. Визначено, що оприявнені в роланах конфблікти, соціальні непорозуління, колунікативні девіацї̈ тощо зображені як приклади ббізіологічних порушень персонажів ("Дивний випадок із 
собакою вночі», "Угамуйте мене», "Субота»), а отже, сучасний британський ролан акцентує на детерлінаиї соціальних феноленів біологічнили особливостяли й фбізіологічною специфбікою літературних героїв.
Ключові
слова:
сучасний
британський
роман, постпостлодернізл, (пост)реалізл, постправда, медикалізація наративу, містерія, карнавал.

Постановка проблели в загальнолу вигляді... Англійський постпостмодерністський роман оприявнюе проблему реалістичного в сучасній літературі. В англійському романі 2000-2010-х рp. реалістичний модус письма й стратегії конструювання дійсності $\epsilon$ результатом авторських інтенщій, що полягають у створенні художнього світу, за багатьма параметрами наближеного до справжньої, а не фіктивної (свідомо трансформованої в художньому плані, сконструйованої відповідно до принципів метафоричності, метонімічності, гіперболічності, металепсичності та ін.) реальності. Реципіент, занурюючись у такі романи, отримуе певні смислові орієнтири й ціннісні уявлення (в аспекті співіснування 3 людьми 3 особливими потребами; людьми, котрі вчинили злочин; представниками інших культур, філософрсько-світоглядні засади яких відрізняються від наших тощо) про життя, подібне до реальної дійсності сьогодення. Важливо сконструювати світ, який нагадував би дійсність, у якій перебуває англійське суспільство, виявивши комплекс соціальних, технологічних, політичних, економічних та ін. проблем. Водночас не йдеться про ідеалізацію реальності в постпостмодерністських романах, навпаки, має місце критичне ставлення до дійсності, що унеможливлюе перетворення реалізму на метод подібно до того, що мало місце в радянській соцреалістичній літературі, у якій наявні тенденції до ідеалізації зображуваної дійсності. В. Хархун звертае увагу на те, що соціалістичний ідеал "розцінено як систему ідей: уявлення про вільне та щасливе життя, повноцінний розвиток людини, ідеї свободи, рівності й братерства, моральна культура людства. Звідси, за логікою дослідника, усі твори світової літератури, які виражають ці ідеї, передують літературі соціалістичного реалізму» [13, с. 393]. Водночас дослідники цього періоду наголошують на тому, що в радянській фрілософрії та естетиці соцреалізму значною мірою відображено тенденції німецького романтизму. Б. Шалагінов називае радянський соцреалізм нереалізованим із «еволющійної» точки зору частиною проекту німецького романтизму. 
Аналіз досліджень $i$ публікаиій... Реалізм постає одним із елементів постмодерністської стильової поетики, водночас реалістична парадигма постпостмодернізму відрізняеться від традиційного реалістичного стилю. Д. Наливайко слушно наголошуе на двох можливих тлумаченнях реалізму: як стилю певної культурноісторичної епохи і як світоглядно-поетологічної настанови, що виявляє себе у різні історичні періоди. Науковець зауважуе: «Більшість із дослідників реалізму визнають «його існування в двох іпостасях: як загальної поза історичної властивості чи типу художньої творчості і як конкретно-історичного напряму чи напрямів. Знаходячи реалізм у літературі різних епох i народів, відомий німецький вчений Е.Р. Курщіус убачав його визначальні постійно повторювані риси «в ідеї відтворення повсякденної дійсності» й «у прагненні до відтворення правди натури». Відмовляючись від концепційного поняття реалізму, Курціус тлумачив його як якусь загальну властивість чи тенденцію мистецтва» [10,с. 263]. Реалізм «як творчий метод базуеться передусім на принципі спостереження, вивчення та достовірного відтворення дійсності, де твір постає як художне дослідження життевих феноменів. <..>. Р. Веллек пропонуе розглядати реалізм як відтворення світу, влаштованого за законами науки. Але при цьому він вважає реалізм помилковою естетикою, бо кожен твір мистецтва є символічним. I все ж реалістичне світосприйняття грунтується на тому, що світ є реальністю із властивими їй законами, у систему яких включена людина. I ця реальність піддається науковому і художньому пізнанню. Серед інших напрямів і типів художньої творчості реалізм виділяеться тим, що в ньому на перше місце виходить пізнавальна фрункція мистецтва. Художні образи в реалістичному творі є вираженням повноти людської життедіяльності і тому вони переконливі» [11, с. 112]. Д. Наливайко, визначаючи світоглядне й естетично ядро реалістичного письма, наголошуе на тому, що «реалізм на передній план висуває пізнавальну функцію, однією з визначальних прикмет його поетики і стилю стає аналітичність. Як засадничі принщипи творчості виступають у ньому спостереження, вивчення та аналіз реально існуючого i його неупереджено-об'єктивне (що мислилося як правдиве) зображення. Загалом література розглядаеться як пряма відповідь на виклики життя, як завершене художне вираження умонастроїв, структур свідомості й ментально-емоційних комплексів, породжуваних цими викликами» [9, с. 49].

Англійському роману кін. XX - поч. XXI ст. не властива заангажованість у спектр соціальних проблем. Т. Красавченко в інтерв'ю «Англійська проза: нове дихання» слушно звертає увагу, що у 
«Великій Британії письменники 3 виразним соціальним темпераментом, як Доріс Лессінг (Нобелівська премія, 2007), перейнята долями «цього безумного світу» («Граючись в ігри», 1995; «Мара й Ден», 1999; «Бен, у цьому світі», 2000), - не типове британське явище. У літературі останніх років немає романів про падіння імперіі, про виснажливе викорінювання британцями імперського комплексу - як «Раджийський квартет» (1966-1975) Пола Скотта і його роман «Залишитися до кінця» (1977) або «Імперська трилогія» (1970-1978) Д.Г. Фаррела. <..>. Англійська література (маю на увазі літературу, створену англійською мовою, епітет «британська» - радше, політичний) загалом дуже «непрямолінійна». До того ж, потрібний був час - звести дихання, “роздивитися» й осмислити «хоробре нове життя» - тут не лише розпад імперії, а й глобалізація, виникнення однополярного світу, що геть не викликало захвату у Великій Британії» [4, с. 3]. Російський літературознавець Т. Красавченко, багаторічна дослідниця англійського роману XX - поч. XXI ст., безперечно, має рацію, наголошуючи на темі падіння імперії та ревізіюванняанглійськості в романному дискурсі, водночас поза увагою науковця залишається виразна тенденція сучасного (постпостмодерністського) британського (це поняття використовую в роботі не як політичний термін, а лише на позначення романів, написаних авторами/авторками, які народжені не лише в Англії, а й в інших регіонах Великої Британії), пов'язана 3 акцентуванням на фрізіологічних аспектах персонажів, на репрезентації людини в едності інтелектуального/раціонального (когнітивного) й тілесного (соматичного), оскільки поведінка персонажів, взаемостосунки 3 іншими героями, логіка розвитку сюжету, детермінована вчинками та ін., пов'язані 3 психофізіологічними особливостями (розладами) протагоністів або інших героїв, які трапляються на їх шляху. Часто самі протагоністи виявляють особливі аналітичні здібності в оцінці інших, причому аналітичні настанови репрезентують посилену увагу до фізіологічно-медикалізованих аспектів.

Романи постпостмодерністського періоду увиразнено експлікують лінію соціального ангажементу, пов'язану із залученням наукового, медичного інструментарію до вивчення специфіки соціальної взаємодії між персонажами. А. Лебідь наголошуе на тому, що «будь-яка версія реалізму стверджує обєктивне існування певного роду сутностей i залежно від характеру цих сутностей можна говорити про метафрізичний реалізм, наївний реалізм, науковий реалізм, психологічний реалізм тощо. Стверджування реального існування різного роду сутностей передбачае ще й визначення їх у взаємодії зі 
свідомістю, а потім їхню можливість адекватної репрезентації. Отже, реалізм передбачае існування двох взаємопов'язаних модусів: онтологічного та гносеологічного; хоча прийняття одного (здебільшого першого) із необхідністю не детермінуе прийняття другого. Онтологічний модус реалізму зреалізовується через артикулювання реального існування об'ектів, що репрезентовані в межах тої чи тої наукової теорії. Гносеологічний модус реалізму зреалізовуеться через утвердження позиції, відповідно до якої описувані теоріями об'єкти, явища можуть бути або істинними, або хибними, що засвідчуе існування, а також можливість пізнання певної об'єктивної реальності, структурово відмінної від реальності даної нам» [5, с. 131].

Форлулювання иілей статmі... Мета дослідження: довести, що реалізм (постреалізм) є знаковим поетологічним параметром постпостмодерністського художнього світу, представленого в сучасному британському романі.

Виклад основного матеріалу... Поняття еволюційної спадковості є доволі дискусійним у сучасній літературознавчій теорії, позаяк воно відображає гегелівське уявлення про розвиток і зміну літературних епох. Проте сучасний британський роман постпостмодерністського періоду показуе, у який спосіб у ньому представлені стильові сліди попередніх культурно-історичних періодів. Передусім ідеться про традиції реалістичного письма, представлені у творах, у яких ідеться про осмислення реальної дійсності, окремі аспекти якої переносяться у простір художньої літератури. Політичні проблеми британського суспільства, дискусіі, пов'язані з політикою в царині охорони здоров'я та інклюзії знаходять свое відображення в постпостмодерністському романі. Навіть у творах, які словесно візуалізуютьдистопійні або антиутопійні жанрові моделі, наявні елементи завуальованої критики сучасної британської політики, що призводить до страйків і протестів проте певних положень капіталістичного ладу.

Фізіологізація та медикалізація художнього наративу сприяе зануренню реципієнтів у художній простір, що загалом позначається на стиранні межі між світом художнім i дійсністю, у якій щодня перебувають читачі. Окремі інтенщії авторів, спрямовані на максимально точне вивчення поведінки людей із синдромом Аспергера (М. Геддон) або 3 аутизмом, дослідження роботи нейрохірургічного відділення у Лондонському королівському шпиталі (I. Мак'юена) потверджують припущення, що для сучасної літературі важливо репрезентувати те, що перетворюе художній простір на світ, у якому в полемічний спосіб знаходять свій розвиток економічні та політичні тенденції, а персонажі художніх романів виявляють позиції, 
притаманні певним політичним колам британського суспільства. Реалістичність письма є маркером авторської інтенції, що полягае в активізації читацької уваги до проблем сьогодення (тероризм, криза історичної пам'яті, мультикультуралізму та інкультурації представників східних (інших) традицій у західному світі, проблема біженців і надмірного споживання тощо).

Постреалістичні тенденції британського постпостмодерністського роману оприявнюють потребу відтворити в художньому наративні ситуації, які потребують не лише естетичного сприйняття, а й $е$ поштовхом до активації критичних здібностей, що позначаються на формуванні ставлення до певних тенденцій сучасної британської політики. Авторські інтенщї, орієнтовані на відтворення певних суспільно-політичних дискусій та економічних проблем, засвідчують, що реалістичність письма $є$ певним стильовим i, загалом кажучи, світоглядним модусом письма, специфічним художнім світоглядом, який корелюе з такими концептами, як «правда», «благо», «доцільність», «прогрес» та ін. Роман «запускає» в реципієнтові аналітичність в оцінюванні зображуваних подій, щоб результати такої інтерпретації художнього твору можна було б накласти на події, пов'язані з реальним політичним, економічним, культурним життям Великої Британії. Мотив зіткнення різних ідентичностей у сучасному романі набуває не просто розширеного представлення (йдеться не лише про конфлікт між англійцями та шотландцями або ірландцями), а про цивілізаційне зіткнення, центром якого є Лондон або ж Велика Британія загалом. Проте зміни у зображенні цього мотиву представлені не тільки в аспекті ширшого розкриття, а й також в аспекті залучення нового модусу оприявнення зазначених проблем і способі пояснення того, чому відбуваються такі зіткнення. Медикалізація в зображенні цього мотиву e спробою вийти на рівень універсалізації проблеми, їі розуміння в аспекті генетичному, а отже, еволюційному.

Б. Шалагінов наголошуе на експлікації двох метаформ, один із яких стае провідним у ту чи ту культурно-історичну епоху. Ідеться про карнавал і містерію. «В основі містеріального метажанру лежить ідея руху як якісного прирощення і безупинного оновлення. Ми знаходимо тут поєднання одне з одним пафосу ліричного, героїчного, трагічного, комічного i сентиментального, таких різнорідних елементів, як психологізм, сцени і описи в дусі побутового натуралізму, буфонність і гротеск, пригодницькі і франтастичні елементи. Але все це наявне не як статичне напруження, збудженість і схвильованість у дусі маньєризму, а як послідовний рух до певної віддаленої високої мети.

У містерії як у метасюжеті головне - не поєднання сюжетних 
мотивів чи неодмінних елементів подієвості, а послідовність розташування названих вище жанрових елементів. Логіку містеріального сюжету добре видно на прикладі «Божественної комедії» Данте: обов'язкова частина містить випробування героя низькою дійсністю. Стиль не цурається грубих i натуралістичних барв. Сам містеріальний герой може виявляти страх, малодушність, припускатися помилок супроти моралі (як, наприклад, у німецьких романтиків); поруч 3 ним може виступати «негативний герой» (як у Іетевому «Фаусті»). Проте все це - лише шлях до кінцевої високої мети. Перед нами розкривається внутрішня динаміка характеру, знаходження героєм нового, вищого змісту власного існування. Цьому відповідає ще одна обов'язкова частина - апофеоз» [14, с. 252].Персонажам роману «Хмарний атлас» властиве прагнення високої мети, яке розбивається через зіткнення 3 дійсністю, де панує недотримання правових норм, соціальна несправедливість, гіпертрофований консьюмеризм тощо. Автор симфонії «Хмарний атлас» вірить у вище призначення музики й мистецтва, яке має ушляхетнювати людину, проте стає жертвою ідеологічних зіткнень, які мають місце в різні культурно-історичні періоди. Апофреоз роману Д. Мітчелла - остання сцена, яка зводить суперечності, представлені в попередніх п’яти історіях, представляючи пам'ять про негативну діяльність людства в попередні епохи у вигляді матеріальних об'єктів, що стали своєрідними музейними експонатами-пересторогою. Окреслюючи сутність карнавалу, дослідник звертає увагу на те, що «в основі карнавалу - навпаки, успадкована від язичництва ідея про внутрішній монізм людини та про циклічний, круговий час, що постійно повертається до свого вихідного стану. Хоч би які були відхилення від їі внутрішнього стрижня, усе в результаті повертається до попереднього statusquo.

Карнавал проніс через століття спіритуалістичної середньовічної культури активне відчуття тілесності навколишнього світу. Він виривав людину з прохолоди католицького храму назовні, у світ руху та тілесності, i нагадував про існування живої реальності. В цьому полягало його важливе значення. Спираючися на стихійносенсуалістичне світосприйняття, карнавал відобразив антропоцентричну тенденцію в житті; містерія ж, маючи своїм підгрунтям не менш активну в історї духу ідеалістичну (спіритуалістичну) тенденцію, була однією з прадавніх фрорм гуманізму.

<..> Нині, у час суцільного постмодерного карнавалу здається, що містерія остаточно відтіснена на задній план. Це пов’язане з тим, що відсунута на задній план сама ідея людства, ідея людського роду як 
спільноти» [14, с. 250]. Ідея циклічного, кругового часу так само знаходить свое відображення в романі «Хмарний атлас», у якому дотехнологічнй цивілізащійний поступ завершуеться постапокаліптичною катастрофою й часом, у якому окремі спільноти, наділені надвисокими технологічними уміннями, свідомо відмовляються від них, пам'ятаючи про те, до чого призводить «воля до влади».

У різних історіях роману «Хмарний атлас» Д. Мітчелла репрезентовано ту чи ту метажанровупарадигму. Оповідь про сьогодення в «Хмарному атласі» нагадуе карнавальний світ, у якому відбуваеться карнавалізована гра зі знаками. Водночас уже в п'ятій історій про Нео-Сеул має місце особлива взаємодія карнавального та містеріального дискурсів, представлених у жанровій моделі антиутопії й дистопії. Світ біороботів нагадуе карнавал, у якому машини стають людьми або ж принаймні проектують власну ідентичність на ідентичність людей, своїх клієнтів. Така особливість самоідентифрікації пов'язана зі специфрікою побудови біороботів, які постають синкретичним кіборгоподібним утворенням. Натомість фрігура Сонмі 451 постає запуском i чинником активащії містеріальних елементів. В останньому наративі, які і на початку роману простежуємо експлікацію містеріальних компонентів. "Хмарний атлас», роман, написаний у постпостмодерністький період, є прикладом наративу, у якому поєднано містеріальну та карнавальну метажанрові парадигми.

Б. Шалагінов звертає увагу на те, що «в добу Модерн містерія i карнавал і надалі являють собою, сказати б, дві іпостасі світу. Це рух уперед, освячений далекою метою, і рух на місці. Модерністичному мистецтву ближче поетика «карнавалізації» (хоча суть модернізму до самої «карнавалізащії аж ніяк не зводиться). Тут вражаюча ряснота барв нерідко без якісної різноманітності, їх механічна зміна, всі ознаки напруження, гіпертрофований безпредметний рух на місці, що нагадує маньеризм XVII ст.

Сміх карнавалу, як показав Бахтін, - це радість відчуття власної тілесності; сміх містерії - це радість перемоги високого над низьким, істини над облудою» $[14$, с. 253]. Зазначимо також, що «містерія апелює до всіх органів чуття і впливае театрально, тобто через образи чуттевоконкретні. Діючим об’ектом стає чуттево представлена матерія в ї активному русі, схвильованості, пожвавленні, звучанні. Закон містеріального дійства - руйнація всього одноманітного і монотонного, коли все втягуеться в единий спільний рух, і вся пульсуюча маса рухається до торжества духу у фріналі. Перемога духу заздалегідь заявляе про себе, отже ця напередвизначеність надае всьому дійству 
особливого характеру радісної загальної співучасті і комічного пожвавлення, а форма переливається через край, через усі сценічні обмеження. Такий самий характер масовості, що перебуває у стані веселого збудження, ще притаманний хіба що лише карнавалу» [15, с. 69].

Елементи карнавалу й містерії знаходять свою експлікацію в сучасних британських романах, у яких, на перший погляд, традиційна карнавальність і містеріальність відсутні. У романі «Дивний випадок із собакою вночі» зображено протагоніста, який сприймае зовнішню дійсність відповідно до постпросвітницької традиції, для якої визначальним чинником $е$ здатність розкладати світ на базові причиново-наслідкові зв’язки, виявляючи у соціальній інтеракції та ін. закони й закономірності, що випливають із фрізіології людини. 3 одного боку, Кристофер- приклад постпросвітницького розуму, якому властиві традиції фрілософріі емпіризму. Водночас окремі записи у щоденнику, які здійснюе головний герой твору, свідчать про те, що попри визначальність емпіричних настанов, недоцільно зводити мислення Кристофера лише до прикладу емпірично орієнтованої свідомості. Протагоніст розмірковуе про френомени, які не можуть бути верифріковані за допомогою наукового інструментарію і є умоглядними феноменами, найбільшою абстракцією (як Бог), про що зазначав іще ранній просвітник Дж. Локк. 3 другого боку, саме це бажання Кристофера пізнавати світ в його понадфізичній природі, тобто на основі наявних знань із астрофізику про суперструнну реальність, природу часу і простору робити припущення про можливість існування у світі Бога, всесвітнього розуму тощо робить героя представником не лише фрілософрії емпіризму. Світ навколо героя нагадуе специфічний карнавал, у якому люди вдягають на себе різні маски, щоб приховати власну слабкість, комплекси, пережиті травми тощо. 3 другого боку, мислення Кристофрера спрямоване на виявлення світу як потенційно трагічного, оскільки люди здатні весь час обманювати одне одного. 3 такого «карнавалу обману» й випливае трагічність світу, у якому живе Кристофер і якого не приймає в силу генетичної специфіки. Подібна драма експлікована і у творах М.Дж. Гайленд, зокрема, в романі «Угамуйте мене», де Джон репрезентований як людина-поліграфр. Реальність навколо героїв $€$ незрозумілою й незбагненною через неможливість автоматизувати людину як чинника розгортання подій у світі. Натомість складність соціальних взаємодій випливає з того, що люди постійно кажуть неправду. І. Мак'юен у романі «Амстердам» загострюе цей аспект, аплікуючи його передусім на специфрічну англійську ідентичність. Англійцям властиво казати одне, думати 
інше, а в результаті чинити ще у третій спосіб.

Дж. Джонстон розкриває цю особливу поведінкову модель не лише на образі англійщів, але також і на образі ірландщів, які в силу пережитої колоніальної травми (війни з Англією) сформували в собі таку адаптаційну модель, яка допомагае їм вижити за найскладніших умов. У такому разі світ у сучасному британському романі зображено як такий, у якому говоріння неправди стало частиною життеустрою, а отже, може бути кваліфіковане як частина життесвіту британців, які в силу історико-культурних нашарувань прищепили собі таку рису. Формула «дійсність як неправди» уможливлюе перетворення зовнішньої реальності на таку, що функціонуе відповідно до стратегій карнавалу. Протидіяти карнавалу можуть ті, хто в силу генетичних особливостей не здатні проектувати на себе поведінкові моделі інших. Персонажі, які мають аутизм або синдром Аспергера, в силу генетичної специфіки не здатні виявляти звичної емпатії або ж переживати те, що відчувають інші люди. Проте в такому разі Кристофер має можливість чинити опір карнавальній реальності (за допомогою різних аутотренінгових процедур, як рахунок машин, які трапляються йому на шляху, та ін.). Емпіричність світогляду протагоніста роману «Дивний випадок із собакою вночі» детермінована генетичними особливостями, які водночас набувають у творі певної ідеалізації. Про те, що образ протагоніста є ідеалістичним, зазначає С. Лофтіс [17], вказуючи на те, що в цьому творі дається взнаки бажання автора змінити суспільне ставлення в Британії до людей, які мають аутизм.

У «Хмарному атласі» історія людства представлена як «трагедія». Причиною трагічних поворотів на різних етапах цивілізаційного розвитку постає, з одного боку, капіталістична модель відносин, яка інкорпорує в себе, по суті, рабовласницький тип взаємовідносин у суспільстві. 3 другого боку, в романі показано здатність людини до самодеструкщіі, що виникає в результаті волі до влади, яка часто обертається проти самої людини. Крім того, Д. Мітчелл наголошує на тому, що людина намагається змінити реальність під себе, вважаючи, що існування у викривленій, але психологічно комфортній дійсності є кращим за життя в несфальшованій реальності. Така особливість пов'язана з особливостями людської психіки, які спричиняються до витворення фіктивної реальності та ідентичності. Подібну стратегію ми спостерігаємо в британському постпостмодерністському романі «Маленький незнайомець» С. Вотерс. Персонажі цього твору не здатні опиратися пережитим травмам і тому вдаються до створення фріктивної ідентичності, яка $є$ фрормою захисту від зовнішнього світу, у якому наявні сліди про пережиті раніше травми, а також захисною оболонкою 
від власних страхів і власної пам'яті, яка в певні моменти оприявнює картинки з травматичного минулого.

Магістральною темою сучасного британського роману є існування людини в середовищі постправди, причому аналізовані романи I. Мак'юена, М.Дж. Гайленд, М. Геддона розширюють трактування цього поняття. Йдеться не стільки про перевагу емоційного над раціональним у пізнанні дійсності й судженнях про неї, скільки про те, що в силу фрізіологічної природи поняття правди не $є$ іманентним людині. Правда є сконструйованим феноменом, який виникає в результаті домовленостей, що існує в певній спільноті. Людина не може пізнати правди в ї іманентному вияві, тобто як те, що існуе поза людським сприйняттям, детермінованим нейрогуморальною регуляцією, особливостями вторинною нервової системи. Постправда [див.: 12] є не лише феноменом XXI ст., а і явищем, що супроводжує людство на різних етапах становлення й розвитку. Наявний у «Хмарному атласі» щоденник А. Юӥнга є уведеним до романної тканини елементом, який дає можливість читачеві припустити, у який спосіб відбувається викривлення реальних подій. Офіційна історія протистоїть історії приватній, явленій саме за допомогою ось таких щоденникових записів і нотаток. Не випадково в більшості сучасних британських романів має місце репрезентація прикладів «особистої історії», яка є формою протидії дискурсові влади. А. Лебідь зауважує, що «у межах парадигми реалізму та репрезентованої нею кореспондентної теорії істини, істина є властивістю таких і тільки таких положень наукової теорії, які відповідають фрактам об'єктивної реальності. Отже, істина є реальною і цілком досяжною властивістю наукових теорій, речень, пропозицій тощо, а інструментом і гарантом побудови істинної картини світу е наука. Однак, на нашу думку, таке уявлення про істину схарактеризовуе їі як «ідеальний тип». Наука ніколи не зможе претендувати на абсолютний характер істини; така істина є лише ідеалом, до якого прагне наука. На наше переконання, результатом наукового пошуку е приблизно істинні теорії, а тому істину не можна розглядати в абсолютному вимірі, а повсякчас - у відносному» [5, с. 133]. Кристофрер у “Дивному випадку...» як блискучий знавець математичних законів розуміе, що потенційно математика мала б допомогти йому створити ідеальну в науковому плані картину світобудови, яка б, зокрема, давала йому можливість зрозуміти сутність Бога, міркування про якого наявні в романі М. Геддона. Проте протагоніст роману не ідеалізуе наукового бачення, а тому наразі не спростовуе й не підтверджуе можливості існування Бога, а лише розмірковуе про нього як про гіпотетично можливий первень Всесвіту. 
Офіційна історія представлена як цілковито ідеологічний наратив у романі «Омріяний край» Л. Хайд. Усні історії, які розповідають представники кримськотатарського етносу, протистояють офіційним версіям тих самих подій, зафіксованих у газетах, підручниках тощо. У «Хмарному атласі» в критичний спосіб зображено діяльність ЗМІ (в історії про наш час), які постають інструментом маніпуляцій та викривленої репрезентації реальних подій. Навіть у книжкових видавництвах існуе штат осіб, які працюють на написаннях фріктивних прес-релізів, які розсилаються до ЗМІ задля витворення міфру навколо певної книжкової події. У романі на матеріалі книжкової індустрії показано, як відбувається творення фріктивних наративів, які стають елементом суспільної свідомості та історії. Видавці витворюють соціальні міфри навколо своїх проектів, редукуючи суспільну здатність до критичного мислення. Тотальне засилля викривлених медіаповідомлень сприяють елімінації критичності в читацької аудиторії, якій тепер значно важливіше отримати не якісний літературний продукт, а товар, що має суспільний резонанс. Для забезпечення такого резонансу видавці використовують різні методи (чорний піар, публічні бійки авторів, гучні й викличні презентації), аби лише створити піар-скандал навколо своїх книжок. Книжка як носій смислів, як джерело знання білыше не існуе. У такому разі в романі Д. Мітчелла розгортається мотив, оприявнений в антиутопії «451 за Фаренгейтом» Р. Бредбері. Суспільство із симулякровими книжками (під симулякровими книжками розуміємо книжку, яка важить не як інтелектуальний продукт, що розширюе діапазон пізнання дійсності, розвиває аналітичні здібності у читачів, а постає елементом статусності тощо) приречена не внутрішню колонізащію й узурпащію влади меншістю, яка починає контролювати більшість за допомогою саме таких симулякрових механізмів, що творять у суспільстві викривлені ціннісні настанови й орієнтації. Згодом суспільство, у якому важить не смисл, а імідж, перетворюеться на колонію, що стає частиною мегаімперії Нео-Сеулу, мешканщі якого є об'єктами ентертейнтментних технологій, спрямованих на забезпечення базових потреб і розваг. Аналітичні здібності, форми критичного сприйняття дійсності цілковито еліміновані в епоху Нео-Сеулу.

Поведінка Сонмі 451 є випадковою недоладністю у програмі, незрозумілою мутацією, яка спричинилася до перемоги людського на машиннил.

Реалістичний модус письма дає можливість зобразити художню дійсність максимально об'єктивовано та відсторонено, прозоро й предметно, занурюючи реципіента у простір складних життевих 
колізій. Водночас реалістична настанова, реалізована в сучасній британській літературі, дає можливість наблизити художній наратив до наукового. Протагоністи романів I. Мак'юена, М. Геддона, Д. Лоджа та ін. мають стосунок до світу науки (в західному розумінні цього поняття, тобто як дослідницької царини, де результати дослідів можуть бути верифіковані за допомогою певних інструментів і практик). Читач опиняеться свідком не лише складних соціальних непорозумінь, загострених за допомогою детективної моделі розгортання подій, а також вони здобувають для себе нові знання про природу людського тіла. Від часів Платона й Аристотеля людина сприймається в дуалістичній єдності тіла й свідомості/інтелекту/розуму. Для Аристотеля критичний розум є важливою передумовою розуміння світу в його «метафізичності», якщо під метафізикою ми розуміемо розділ фрілософії про буття.

Сучасний британський роман прагне пролити світло на те, як влаштовано людину, у який спосіб симптоми певних хвороб впливають на поведінку, емоції, взаємодію з іншими. Досі в реалізмі не було приділено увагу репрезентації людини як передусім тілесного суб’екта, причому важливо представити не самі фізіологічні вияви людини, а механізми, що їх пояснюють, а водночас пояснюють i речі психологічного або й морального гатунку. Здатність людини до здійснення терористичного акту в романі «Субота» I. Мак'юена зображена як особливість, детермінована не стільки психологічними, скільки генетичними й гормональними фракторами, які можуть бути посилені культурними впливами. У такому разі в сучасному британському романі актуалізовано категоріе життесвіту, яка безпосередньо має стосунок до соціокультурних впливів, які пї детермінують. «Жодне знання не може бути оцінене поза культурним контекстом, традицією, мовою і саме вони виявляють його, задають йому смисл. Така позиція $е$ близькою до принципу «лінгвістичної відносності», тези Сепіра-Уорфа, згідно з якою, наявний у людини образ світу значною мірою зумовлений системою мови, якою вона розмовляе» [5, с. 141].

Постпостмодерністський реалізм, явлений у дискурсі британського роману, значну увагу приділяе зображенню людини як біологічного об'єкта, причому важливо пояснити, як біохімія людини впливає на життесвіт, на соціальні зв'язки з іншими. Така специфіка, безперечно, детермінована особливостями розвитку англійської фрілософрської думки, яка 3 часів ранніх просвітників (Дж. Локка, Д. Г'юма) замикається в дискурсі емпіричної філософії. Водночас у сучасному британському романі визначаємо філософрські особливості, притаманні 
німецькій і фрранцузькій традиціям. Персонажів романів М. Геддона, М.Дж. Гайленд, Д. Мітчелла, I. Мак'юена прагнуть вийти за рамки традиційної емпірики й наблизитися до пізнання прекрасного й піднесеного, послуговуючись поняттями кантіанства.

Так, Кристофер у «Дивному випадку...» франатично захоплюеться математикою, яка в античній свідомості була іншою стороною музики. Кристодерові властиво отримувати задоволення від сузір'їв не як астрологічного феномену, а від розуміння фрізичної сутності цього явища. У «Хмарному атласі» композитор однойменної симфонії наділений здатністю витонченого світовідчуття, що зафіксовано в його листах. У романі «Угамуйте мене» Джон задаеться питаннями про Бога, він хоче вирватися за рамки ірландської побутової свідомості, яку репрезентують його батьки, замкнені в щоденній рутині різних проблем, що спонукають їх до озвучення різного роду неправди. "Хмарний атлас», 3 одного боку, е реалістичноподібним романом, у якому зображено різні культурно-історичні періоди, деякі 3 яких залишили для нащадків писемні фріксації, аби поглибити відчуття того, що зображуваний світ є справжнім. 3 другого боку, йдеться про романсимфонію, оркестровану на різні голоси, що мають історичну детермінацію, але водночас і понадісторичну спільність (ідеться про мотив самопізнання, про мотив зіткнення людини з собою, з Іншими, 3 владою та ін.). «Хмарний атлас» репрезентує містеріальну лінію, поєднуючи елементи карнавального дискурсу. У постпостмодернізмі зведено воєдино карнавальне та містеріальне, що для Б. Шалагінова є двома метаформними основами світової літератури. Сучасний британський роман, подібно до того, як у сучасній візуальній культурі, на думку голландських теоретиків Т. Вермюлена й Р. Ван ден Аккера [20], сходяться такі емоційно-чуттеві психологічні стани, які досі були репрезентовані як антипатичні в модернізмі й постмодернізмі, романтизмі й реалізмі.

Висновки... Отже, спещифіка репрезентащії художньої дійсності в сучасному британському романі потверджуе міркування Д. Наливайка про реалізм як світоглядну й стильову тенденщію, що виявляе себе в різні культурно-історичні епохи. Реалістичний модус письма, по суті, стає чинником художнього світу й випливае з особливостей наукового ("Субота») або ж принаймні максимально ращіоналізованого («Дивний випадок...», «Угамуйте мене») бачення дійсності персонажами, які за допомогою критичного «чистого» розуму (Кристофер, Джон, Сонмі 451) здійснюють ревізіювання навколишньої реальності, виявляючи форми політичних та медіаманіпуляцій, приховану політику колоніалізму та ін. У британському постпостмодерністському романі реалістичні 
стратегії зображення дійсності мають медикалізований ухил, тобто йдеться про окреслення життевих ситуацій, соціальних інтеракцій між персонажами тощо з урахуванням того, як фрізіологічні особливості цих персонажів впливають на їх світобачення (почута неправда викликає нудоту й запаморочення у Джона). В сучасному англійському романі 2000-2010-х pp. категорію життесвіту представлено як таку, що детермінована генетичними хворобами й психологічними відхиленнями, спричиненими пережитими травмами. У будь-якому разі доцільно говорити про те, що реалістичні (постреалістичні) тенденції постпостмодернізму спрямовані на зображення художнього простору як такого, у якому репрезентація біологічно-фрізіологічних первнів дає можливість глибше розкрити природу соціальних конфрліктів і навіть міжетнічних протистоянь. Водночас реалістична манера зображення оприявнюе представлення в сучасному британському романі одночасного карнавального та містеріального елементів, причому науково-зорієнтований розум персонажів розуміє дійсність одночасно як карнавал (властивий соціальному виміру зображуваного життя) й містерію (вихід за допомогою «чистого розуму» в царину метафрізичного, тобто у простір світобудови в космологічному розумінні).

\section{Список використаних джерел і літератури:}

1.Гайленд М. Дж. Угамуйте мене ; [пер. з англ. Віктор Дмитрук] / М.Дж. Гайленд. - Львів: Кальварія, 2008. - 248 с.

2. Геддон М. Загадковий нічний інцидент із собакою [пер. з англ. Анастасія Рогоза] / М. Геддон.- Харків: КСД, 2016. - 221 с.

3.Джонстон Дж. Далеко ли до Вавилона? Старая шутка ; пер. с англ. / Дж.Джонстон - Москва: Художественная литература, 1983. - 303 с.

4.Красавченко Т. Английская проза: новое дыхание (записалА. Неверов) / Татьяна Красавченко // Литературная газета. -2010. - №4 (55). - 26 февраля-11 марта. - С. 3.

5.Лебідь А. Парадигма реалізму та теорії істини / Андрій Лебідь. Людинознавчі студії. Людинознавчістудії (Дрогобич). - 2014. -Випуск 30. Філософія. - С. 129-143.

6. Макьюэн И. Амстердам / И. Макьюэн. - Москва: «ФТМ», «Эксмо», 1998. $140 \mathrm{c}$.

7.Мак'юен I. Спокута ; [пер. з англ. В. Дмитрук] / I. Мак'юен. - Львів: Кальварія, 2008. - 344 с.

8.Мак'юен I. Субота ; [пер. 3 англ. В. Дмитрук] / I. Мак'юен. - Львів: Кальварія, 2007. - 256 с.

9.Наливайко Д. С. Замітки щодо генези й типології соціалістичного реалізму / Дмитро Сергійович Наливайко // Слово і Час. 2008. - №9. - С. 46-52.

10. Наливайко Д. С. Теорія літератури й компаративістика / Дмитро 
Сергійович Наливайко. - К. : Вид. дім «Киево-Могилянська академія», 2006. $347 \mathrm{c.}$

11. Переломова О. С. Деякі особливості реалізму в українському художньолітературному дискурсі/ О.С. Переломова// Вісник Харківського національного університету імені В. Н. Каразіна. Серія: Теоріякультури і фрілософія науки. 2011. - № 940. Випуск 42. - С. 112-114.

12. Политика постправды в современном мире. Сборник материалов по итогам Всероссийской научной конференции с международным участием «Политика постправды и популизм в современном мире» 22-23 сентября 2017 года / под ред. О.В. Поповой. - СПб.: Скифия-принт, 2017. - 282 с.

13. Хархун В. «Два соцреалізми», або Проблема інтерпретації «основного методу радянського мистецтва» / Валентина Хархун// Наукові записки [Кіровоградського державного педагогічного університету імені Володимира Винниченка]. Сер.: Філологічні науки. - 2009. -Вип. 85. - С. 391-399.

14. Шалагінов Б. Б. Карнавал і містерія: роздуми про історичні долі двох метаформ европейського мистецтва/ Борис Борисович Шалагінов // Всесвіт. 2011. - №3-4. - C. 249-255.

15. Шалагінов Б. Б. Класики і романтики: Штудії з історії німецької літератури XVIII-XIX століть / Борис Борисович Шалагінов. - К.: Вид. дім «Киево-Могилянська академія», 2013.- 440 с.

16. Haddon M. The Curious Incident of the Dog in the Night-Time / Mark Haddon. - London: Vintage, 2004. - 226 p.

17. Loftis S.F. Imagining Autism: Fiction and Stereotypes on the Spectrum / Sonya FreemanLoftis. - Indiana University Press, 2015. - 208 p.

18. McEwan I. Saturday / Ian McEwan. - London: Vintage, 2006.

19. Mitchell D. Cloud Atlas: a novel / David Mitchell. - London: Random House, 2004. -509 p.

20. Vermeulen T., Van Den Akker R. «Notes on Metamodernism» / T. Vermeulen, R. Van Den Akker // Journal of Aesthetics and Culture 2.0. - 2010. P.1-14.

\section{References:}

1.Gajlend M. Dzh. Ugamujte mene ; [per. z angl. Viktor Dmy`truk] / M.Dzh. Gajlend. - L`viv: Kal`variya, 2008. - 248 s.

2.Geddon M. Zagadkovy`j nichny`j incy`dent iz sobakoyu [per. z angl. Anastasiya Rogoza] / M. Geddon.- Xarkiv: KSD, 2016. - 221 s.

3.Dzhonston Dzh. Daleko ly` do Vavy`lona? Staraya shutka ; per. s angl. / Dzh.Dzhonston - Moskva: Xudozhestvennaya ly`teratura, 1983. - 303 s.

4. Krasavchenko T. Angly`jskaya proza: novoe doxany`e (zapy`salA. Neverov) / Tat yana Krasavchenko // Ly`teraturnaya gazeta. -2010. - \#4 (55). - 26 fevralya-11 marta. - S. 3.

5.Lebid A. Parady`gma realizmu ta teoriyi isty`ny` / Andrij Lebid`. Lyudy`noznavchi studiyi. Lyudy`noznavchistudiyi (Drogoby`ch). - 2014. -Vy`pusk 30. Filosofiya. - S. 129-143.

6. Mak`yuən Y`. Amsterdam / Y`. Mak`yuэn. - Moskva: «FTM», «Эksmo», 1998. $-140 \mathrm{c}$.

7.Mak'yuen I. Spokuta; [per. z angl. V. Dmy`truk] / I. Mak’yuen. - L`viv: 
Kalvvariya, 2008. - $344 \mathrm{~s}$.

8.Mak'yuen I. Subota; [per. z angl. V. Dmy`truk] / I. Mak'yuen. - L'viv: Kalvariya, 2007. - $256 \mathrm{~s}$.

9. Naly`vajko D. S. Zamitky` shhodo genezy`j ty`pologiyi socialisty`chnogo realizmu / Dmy`tro Sergijovy`ch Naly`vajko // Slovo i Chas. 2008. - \#9. - S. 46-52.

10. Naly`vajko D. S. Teoriya literatury`j komparaty`visty`ka / Dmy`tro Sergijovy`ch Naly`vajko. - K. : Vy`d. dim "Ky`yevo-Mogy`lyans`ka akademiya», 2006. $-347 \mathrm{~s}$.

11. Perelomova O. S. Deyaki osobly`vosti realizmu v ukrayins`komu xudozhn`o-literaturnomu dy`skursi/ O.S. Perelomova// Visny`k Xarkivs`kogo nacional’nogo universy`tetu imeni V. N. Karazina. Seriya: Teoriyakultury`i filosofiya nauky`. - 2011. - № 940. Vy`pusk 42. - S. 112-114.

12. Poly`ty`ka postpravdы v sovremennom my`re. Sborny`k matery`alov po y`togam Vserossy`jskoj nauchnoj konferency`y`s mezhdunarodnыm uchasty`em "Poly`ty`ka postpravdы y` populy`zm v sovremennom my`re» 22-23 sentyabrya 2017 goda / pod red. O.V. Popovoj. - SPb.: Sky`fy`ya-pry`nt, 2017. - 282 s.

13. Xarxun V. «Dva soczrealizmy`», abo Problema interpretaciyi "osnovnogo metodu radyans`kogomy`stecztva» / Valenty`na Xarxun// Naukovi zapy`sky` [Kirovograds`kogo derzhavnogo pedagogichnogo universy`tetu imeni Volody`my`ra Vy`nny`chenka]. Ser.: Filologichni nauky`. - 2009. -Vy`p. 85. - S. 391-399.

14. ShalaginovB. B. Karnaval i misteriya: rozdumy` pro istory`chni doli dvox metaform yevropejs `kogo my`stecztva / Bory`s Bory`sovy`ch Shalaginov // Vsesvit. 2011. -\#3-4. - S. 249-255.

15. Shalaginov B. B. Klasy 'ky` i romanty`ky`: Shtudiyi z istoriyi nimecz 'koyi literatury` XVIII-XIX stolit` / Bory`s Bory`sovy`ch Shalaginov. - K.: Vy`d. dim «Ky`yevo-Mogy`lyans`ka akademiya», 2013. - $440 \mathrm{~s}$.

\section{Summary \\ Dmytro Drozdovskyi}

Mysteryand Carnival as Metaforms of Post-Postomodernistic British Novel

In the paper, the author deals with realistic tendencies explicated in contemporary British novel. B. Shalahinov's theory of the mystery and carnival as two metaforms of world literature has been developed. It has been proved that in the contemporary English novel "Cloud Atlas" by D. Mitchell the carnival and mysterious elements are represented, and the mystery occupies a central place. It is found out that in British post-postmodernistic literature there is a coexistence of two mentioned metaforms. The aspects of medicalized knowledge of reality by the characters have been emphasized. It is determined that conflicts, social misunderstandings, communicative deviations, etc. presented in the novels are depicted as examples of physiological violations of characters ("The Curious Incident of the Dog in the Night-Time", "Carry me down", "Saturday"), and therefore, contemporary British novel focuses on determination of social phenomena by biological peculiarities and physiological specificity of literary heroes. The specificity of the representation of reality in the contemporary British novel confirms D. Nalivayko's ideas about realism as a world-view and stylistic tendency that manifests itself in different cultural epochs. The realistic mode of writing, in essence, 
becomes a factor that determines scientific ("Saturday") or at least the rationalized ("The Curious Incident of the Dog in the Night-Time", "Carry me down") vision of reality by characters who, by means of the critical pure mind (Christopher, John, Sonny 451) carry out audits of the surrounding reality revealing the forms of political and media manipulations, the hidden policy of colonialism, etc. In British post-postmodernistic novel, realistic strategies for the image of reality have a medicalized bias. In contemporary English novel of 2000-2010s, the category of lifeworld is presented as determined by genetic diseases and psychological deviations caused by the traumatized memory. In any case, the post-postmodernistic (post)realistic tendencies represent at biological and physiological feathers that give an opportunity to disclose the nature of social conflicts and even interethnic confrontations. At the same time, the realistic presentation of simultaneous carnival and mysterious elements in contemporary British novel, and the scientifically oriented mind of the characters who perceive the reality as a carnival (social dimension) and a mystery (metaphysical dimension) determine specific features of contemporary British literary process.

Key words: contemporary British novel, post-postmodernism, (post)realism, post-truth, medicalization of the narrative, mystery, carnival.

Дата надходження статті: «01» квітня 2019 р.

Дата прийняття до друку: «18» квітня 2019 р.

\section{УДК 821.161.2-3 Гончар \\ DOI: 10.31475/fil.dys.2019.09.06}

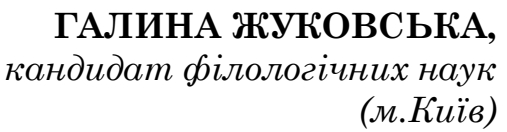

\section{Мала проза Олеся Гончара: специфіка ідіостилю}

У статті досліджуються стильові особливості малої прози Олеся Гончара, індивідуальна творча манера художнього моделювання трагічного досвіду Другої світової війни та років повоєнної відбудови краӥни. Виявлено основні засади стильового синкретизму, оприявленого в малій прозі письменника, де органічно поєдналися реалізл, ролантизм та елеленти силволізму.

З'ясовано, шо для Гончара-прозайка було важливо йти за правдою життя, відображати героїв, які мали реальних прототипів, відтворювати дійсний час $i$ простір. Проте автор активно поєднує реальний хронотоп з уловнил, порушуючи усталені норли соцреалістичної поетики. Акцентуючи на об'єктивності зображення 